\title{
ПАРАДИГМАТИЧНІ ТА СИНТАГМАТИЧНІ ЗВ'ЯЗКИ ЯК ВИЯВ СИСТЕМНОСТІ БІБЛІЇЗМІВ УКРАЇНСЬКОЇ МОВИ
}

\author{
НАТАЛІЯ ПІДДУБНА \\ Харківський національний педагогічний університет імені Г. С. Сковороди, \\ Харків - Україна \\ piddubnan71@gmail.com; ORCID: 0000-0003-0331-0496 \\ RELACJE PARADYGMATYCZNE I SYNTAGMATYCZNE JAKO PRZEJAW \\ SYSTEMOWOŚCI BIBLIZMÓW JĘZYKA UKRAIŃSKIEGO \\ NATALIA PIDDUBNA \\ Charkowski Narodowy Uniwersytet Pedagogiczny imienia Hryhorija Skoworody, \\ Charków - Ukraina
}

STRESZCZENIE. Artykuł poświęcony jest badaniu systemowych (syntagmatycznych i paradygmatycznych) relacji leksykalnych i frazeologicznych biblizmów języka ukraińskiego. Wykazano, iż zmiana relacji syntagmatycznych wpływa na stosunki paradygmatyczne, $\mathrm{w}$ rezultacie czego biblizmy ulegaja desakralizacji, a w ich systemie mają miejsce zjawiska enantiosemii, antynomii, homonimii, jak również przeintegrowanie znaczeń. Dla biblizmów charakterystyczne są synonimiczność, wieloznaczność i wiarantywność, hipero- i hiponimia, co również potwierdza ich systemowość.

Słowa kluczowe: biblizm, relacje syntagmatyczne, relacje paradygmatyczne, synonimiczność, wieloznaczność, wariantywność, hipero- i hiponimia.

\section{PARADIGMATIC AND SYNTAGMATIC RELATIONSHIPS AS A PROOF OF SYSTEMICITY OF BIBLEISMS IN THE UKRAINIAN LANGUAGE}

\section{NATALIIA PIDDUBNA}

H. S. Skovoroda Kharkiv National Pedagogical University, Kharkiv — Ukraine

ABSTRACT. The article is aimed at studying of the systematic (syntagmatic and paradigmatic) ties of the lexical and phraseological bibleisms in the Ukrainian language. It has been proved that the change of the syntagmatic relations influences the paradigmatic ones; as a result, the bibleisms are desacralized, andenanthisemia, antonymy, homonymy and the reintegration of meanings appear. The bibleisms are characterized by synonymy, polysemy and variability, hyper-hyponymy that also prove their systemicity.

Key words: bibleism, syntagmatic relations, paradigmatic relations, synonymy, polysemy, variability, hyper-hyponymy.

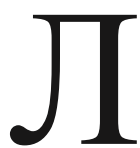

інгвістичні дослідження останніх років усе частіше присвячуються проблемі статусу бібліїзмів, функціювання біблійної лексики й фразеології в сучасній українській мові, виявам у ній біблійності. Увагу авторки цієї наукової розвідки привернуло питання системності бібліїзмів, що раніше не було предметом спеціального дослідження, однак є важливим для розуміння ролі й місця цих одиниць в українській мові.

Як і кожному іншому мовному знаку, бібліїзму, чи то лексичному, чи фразеологічному, властива системність — ,існування мовного знака в обов’ язковому 
взаємозв'язку з іншими знаками"1, що виявляється, зокрема, у синтагматичних і парадигматичних відношеннях.

Унаслідок наявності синтагматичних відношень, за яких між значенням слова та його сполучуваністю існує тісний зв'язок, розширення чи зміна сполучуваності слова спричиняється до зміни його значення. Це унаочнює й низка бібліїзмів, що в процесі засвоєння змінювали своє первинне значення. Зрозуміло, що це насамперед стосується постбіблійних фразеологізмів, що стали узагальнено-образними зворотами в національних мовах завдяки метафоричному осмисленню, напр. терновий вінецьь, нести свій хрест та ін. Однак зміна значення бібліїзмів спостерігається й у тих одиницях, що вживалися як ФО вже в тексті Святого Письма. Напр., ФО чаша терпіння переповнилася (переповнена) в Біблії в одному зі псалмів Давида символізує достаток й означає 'усі мої мрії збулися, мені більше нічого бажати', порівн.: Ти передо мною трапезу зготовив при моӥх ворогах, мою голову Ти намастив був оливою, моя чаша то надмір пиття! (Пс. 22:5). У сучасних мовах цей вираз означає 'немає жодної можливості терпіти, виносити щось, про ситуацію, коли неможливо більше виносити якийсь стан справ (про образливі для когось слова чи вчинки) ${ }^{3}$. Дослідники вважають, що в процесі функціювання виразу його зміст змінився під впливом іншого - нехай обмине ияя чаша мене, і він набув не позитивних, а негативних конотацій (Мат. 26:39), випити <до дна><гірку (повну)> чашу (Вих. 51:17, 21-23; Ієр. 25:15-17; Є3. 23:31-35), а також у результаті розширення компонентного складу звороту елементом 'терпіння'.

Зміна семантики бібліїзмів часто спричинена десакралізацією мовних одиниць, що також значною мірою є виявом синтагматичних відношень, за якої вони в повсякденному спілкуванні поступово переходять із сакральної, релігійно-культової сфери у сферу побутову, i, зрештою, багато бібліїзмів „суттєво змінюють свою семантику порівняно з біблійними прототипами".

У деяких лексемах-бібліїзмах як наслідок синтагматичних відношень розвиваються не лише нові значення, але й змінюється оцінка. На це вказує Т. Космеда, яка зауважує, що лексеми диявол, сатана, чорт і похідні від них, хоч і мають негативну семантику, однак ,можуть називати і те, що викликає подив, захоплення, а в результаті цього, буває, й позитивну оцінку (порівн.: диявольська краса, диявольські здібності тощо)"'. Це ж стосується й біблійних фразеологізмів, що в сучасному мовленні можуть змінювати конотацію. Зазначене можна простежити на прикладі ФО золотий телець, який у мові має негативну конотацію, оскільки означає 'багатство, збагачення як єдина мета життя'7. Однак у сучасному інтернет-дискурсі цей ситуативний бібліїзм часто набуває позитив-

${ }^{1}$ А. Загнітко, Словник сучасної лінгвістики: поняття $і$ терміни, у 4 томах, Донецьк 2012, т. 3, с. 287.

2 Лепта библейской мудрости: библейские крылатые выражения и афоризмы на шести языках: краткий русско-англо-белорусско-немеияк-словачко-украинский словарь, Могилев 2014 , c. 202.

3 Там само.

4 К. Дубровина, Библейские фразеологизмы в русской и европейской культуре, Москва 2012, [в:] Электронный peсурс: http://modernlib.ru/books/kira_nikolaevna_dubrovina/bibleyskie_ frazeologizmi_v_russkoy_i_evropeyskoy_kulture/read/ (15.11.2017).

5 Там само.

6 Т. Космеда, Аксіологічні аспекти прагмалінгвістики: формування і розвиток категорії очінки, Львів 2000, с. 28.

А. Коваль, Спочатку було Слово: Крилаті вислови біблійного походження в українській мові, Київ 2012, с. 70. 
ної конотації під впливом того, що його часто використовують як назву (“ЗЗлотий тілець”) для ювелірних компаній, ювелірних магазинів, ресторанів тощо ${ }^{8}$.

Явну іронічну, а то й саркастичну конотацію в мовленні має й бібліїзм розумний як Соломон у разі, коли він уживається не з усталеним значенням 'дуже розумний', а, навпаки, 'дурний'. У цьому разі, як зазначає I. Кузнецова, ,протиріччя планів змісту й вираження може виявлятися й на мовленнєвому рівні"9. Фактично, простежуємо наслідок, що мотивований зміною синтагматичних відношень, його вияв у системі парадигматичних відношень, коли в мовній одиниці розвивається енантіосемія.

Ще одним яскравим прикладом того, як зміни в синтагматиці спричиняють зрушення й у парадигматичних відношеннях, є цитатний бібліїзм убогі духом, що виник на основі актуалізації фрагмента Нагірної проповіді Ісуса Христа, де сказано: Блаженні вбогі духом, бо їхнєє Царство Небесне (Від Матвія 5:3). У Святому Письмі вбогий духом - це 'та людина, яка щиро визнає й завжди переконана, що іiі розум, мудрість, сила перед Богом нічого не варті, що вона нічого свого не має, а має лише те, що їй дає Господь'. Адже убогий духом знає, що власними силами він нічого доброго не зробить, якщо Господь не допоможе йому, пославши благодать Духа Свого. Ідеться про того, хто вважає себе найбільшим грішником, гіршим і нижчим за всіх інших, хто завжди собі дорікає і нікого не засуджує; ніколи не покладається на себе, а у всьому вдається до милосердя Божого. Убогість духовну святий Іоанн Золотоуст коротко зве «смиренномудрієм»"10.

У сучасних мовах, принаймні українській і російській, ФО убогі духом (рос. нищие духом) означає 'люди з убогим розумом, позбавлені духовних інтересів', тобто в ньому розвинулася енантіосемія як протиставлення смислів 'глибока духовність', 'визнання Бога як найвищої сили', 'смиренність', з одного боку, й 'бездуховність', 'заперечення моральних цінностей', 'богозневага' - 3 другого.

Як приклади розширення значень бібліїзмів (появу нових парадигматичних відношень, зокрема полісемії) через зміну синтагматичних відношень можна навести ФО Йов праведний (Йов багатостраждальний), що слугує для номінації людини, яка зазнала багато горя, злиднів, але через десакралізацію набуває іронічної або жартівливої конотації й нового значення —'той, хто вдає із себе страдника, нещира людина, що прибідняється’. О. Валентинова вбачає причину цього у відчуженні сакрального знака від канонічного смислоформувального контексту, унаслідок чого такий знак десакралізується. Вона зауважує: „Символічні значення вилучених із канонічних текстів знаків, що засвідчували достовірність невидимого буття, руйнуються в першу чергу"11.

8 О. Бурукина, Цвета библейских фразеологизмов: истоки иветового символизма, [в:] Славянская фразеология и Библия. Slovanska frazeologia a Biblia, W. Harry, V. Mokienko, D. Balakova (ur.), Greifswald 2013, c. 59.

9 И. Кузнецова, Языковая шутка в устойчивых сравнениях с персонажем Библии, [в:] Славянская фразеология и Библия. Slovanska frazeologia a Biblia, W. Harry, V. Mokienko, D. Balakova (ur.), c. 125 .

${ }^{10}$ Перша заповідь блаженств: “Блаженні вбогі духом, бо таких є Царство Небесне”, [в:] Електронний ресурс: http://www.truechristianity.info/ua/books/hope_for_lord_031.php (22.12.2017).

${ }^{11} \mathrm{O}$. Валентинова, О семантических последствиях отчуждения сакрального знака от канонического смыслообразующего контекста, [в:] Фразеологизм и слово в художественном, публицистическом и народно-разговорном дискурсах, матер. междунар. науч.-практ. конф.1823 марта 2016 года, под науч. ред. Ю. Третьяков ой, Кострома 2016, с. 80. 
У сучасній українській мові як наслідок зміни синтагматичних відношень не лише виникають нові десакралізовані значення й ФО стає полісемантичною, а й відбувається переінтеграція значень, за якої „в процесі розвитку семантичної структури слова на місце прямого номінативного виходить одно з етимологічно похідних" ${ }^{2}$. Це явище грунтовно дослідила Л. Лисиченко, яка на прикладі низки релігійних лексем показала переінтеграцію їхніх ЛСВ, унаслідок чого вони звужують релігійну семантику. Напр., у лексемі іменини на сьогодні як пряме номінативне сприймається колись похідне 'річниця від дня народження кого-небудь', а не етимологічно пряме 'у православних і католиків - особисте свято кого-небудь, що припадає на день, у який церква відзначає пам'ять однойменного святого'. Простежуємо переінтеграцію ЛСВ, що веде до певного зміщення структури лексичного значення цього слова.

Слово кумир, що у своїй структурі мало спершу пов'язане з релігією значення 'статуя, якій язичники поклонялися як божеству', із часом стало означати 'той, хто служить предметом захоплення, поклоніння'

Подібне відбувається й із ФО всевидюще око (всевидящеє око), узятого 3 християнської символіки, у якій „промисел Божий зображується в променях, обрамленого трикутником і означає Бога, усюдисущого й усезнаючого"14. Саме внаслідок процесу переінтеграції носії сучасної української мови як пряме номінативне значення фраземи всевидюще око (всевидящеє око) сприймають нерелігійне десакралізоване значення, що відображене в словнику фразеологізмів української мови, де ця одиниця тлумачиться як 1. 'Здатність все помічати, бачити, про все швидко дізнаватися, знати', напр. Всевидюще око двадиятирічного командира слідкувало за всіма розрахунками (М. Стельмах); Всевидяче око його вже проникало в глибину шеренг, когось невтомно шукало $(\mathrm{O}$. Гончар); Tут його [Франка] рятує від смерті один з його товаришів $і$ забирає з собою на село. Але й там видюче око адміністрачії постерегло небезпечного злочиния (М. Коцюбинський); 2. уроч., заст. 'Всевишній', напр.: А ти, Всевидящеес око! Чи ти дивилося звисока..? Та иур їм, тим царям поганим! Нехай верзуться ӥм кайдани (Т. Шевченко) ${ }^{15}$.

Наслідком десакралізації $є$ й значення, яких набула ФО агнець божий (боже ягня), що в українській мові вживається іронічно й означає таке: 'Безвольна, покірлива, розумово обмежена людина' ${ }^{16}$, напр.: Бачии, агнець божий, покірний, тихий перед тобою, а що він у бригаді виробляв, хай тобі люди розкажуть! (3 журналу); по-друге, уживається на позначення смирної громади, яка не має власної думки, сліпо йде за провідцями, порівн.: Ти захотів у безконечне поле / Ягнят святої иеркви розігнати... / А де там пама? Де зелені трави? / Де Божий затишок від злочину і страху (О. Бердник) ${ }^{17}$. Як видається, наведена ілюстрація до першого значення цієї ФО демонструє наявність іще одного значення: 'лицемір, брехун, який удає із себе сумирну, беззахисну жертву'. Його зафіксувала російська дослідниця К. Дубровіна ${ }^{18}$, тоді як в Апокаліпсисі агнець божий означає 'той, перед ким усі падали ниць і співали', порівн.: Ти достойний узяти ию книгу і розкрити печатки ї̈, бо Ти був заколений $і$ кров'ю Своєю

\footnotetext{
12 Л. Лисиченко, Лексико-семантична система украйнської мови, Харків 1997, с. 48.

13 Там само, с. 49.

14 А. Коваль, зазнач. джер, с. 288.

15 Словник фразеологізмів української мови, Київ 2008, с. 463.

16 Там само, с. 19.

17 А. Коваль, зазнач. джер, с. 259.

18 К. Дубровина, указ. источ.
} 
Ти викупив людей Богові з усякого племені, і язика, $і$ народу, і люду (Апокаліпсис, 5: 9). Оскільки, як зазначає А. Коваль, Агнець Божий - це Ісус Христос, який своєю кров'ю змив людські гріхи. Він відкрив книгу за сімома печатями (Апокаліпсис, 6: 1-8) ${ }^{19}$.

Отже, можемо розмірковувати про наявність омонімії між виразами, що функціюють у біблійному тексті, й ФО-бібліїзмами. Це стосується як тих фразеологізмів, метафоризація яких відбувається в Біблії, так і постбіблійних ФО, як напр., воскресіння Лазаря, страха ради іудейська, не від світу иъього та ін. ФО-бібліїзм страха ради іудейська, як зазначає А. Коваль, відійшов ,дуже далеко від свого первісного значення" внаслідок неправильного перекладу із церковнослов' янської мови як “заради іудейського страху”, тоді як він перекладається інакше - “заради страху перед іудеями”, тому сьогодні „він означає "страх перед сильними світу цього і загалом перед будь-якою силою"'20, напр.: Багатство автографів із найдавніших часів, починаючи 1861 роком, дає можність контролювати всякі зміни, роблені в різних часах різними редакторами в Федьковичевих творах, декуди доповнювати пропуски, роблені редакторами чи то для якихось власних уподобань, чи «страха ради іудейська»"(І. Франко).

Бібліїзм не від світу иього (нє от міра сєго) в Новому Заповіті означає 'те, що належить не цій, не земній дійсності, тобто якомусь священному простору’21 й має винятково позитивну конотацію, однак у сучасній українській мові „так говорять про людей, які перебувають у світі мрій, людей, далеких від турбот сьогодення, про звичайні земні справи"22. Цей бібліїзм у мовленні часто репрезентує конотацію іронії, несхвалення. За спостереженнями О. Асенчик, він став вербалізувати іншу, ніж у Біблії, оцінку, адже якщо в Новому Заповіті сформувалося уявлення про людину не від світу цьього як про носія найвищих християнських чеснот (скромності, смирення, чистоти помислів, прагнення робити добро), то в сучасних мовах — про людину, абсолютно не пристосовану до життя, дивакувату, тобто „метафоричне переосмислення виразу пішло шляхом від позитивного до негативного"23.

Окрім цього, омонімічні зв'язки виявляються й серед бібліїзмів, що вживалися ще в самому Святому Письмі. За спостереженнями Т. Варлакової, такі фразеологізми, „хоча й розвинули світське значення, зберігають зв'язок зі своїм першоджерелом. Цей зв'язок може виявлятися через актуалізацію внутрішньої форми фразеологізмів у певних контекстних умовах. Процеси омонімізації, утворення формально тотожних, але різних за своїми значеннями ФО, що сягають біблійних текстів, - вияв постійної еволюції мовної системи. Особливості семантики й функціювання досліджуваних омонімів демонструють багатий потенціал, яким володіють ФО біблійного походження" 24.

Низка біблійних ФО утворює синонімічні пари й ряди, як напр., відділяти овець від козлищ, відділяти кукіль від пшенищі, що означають 'відділяти погане

19 А. Коваль, зазнач. джер, с. 280.

20 Там само, с. 262.

21 Е. Асенчик, О глубинной семантике фразеологизма не от мира сего, [в:] Славянская фразеология в ареальном, историческом и этнокультурном аспектах, матер. III Междунар. науч. конф. (Гомель, 7-8 октября 2003 г.), Гомель 2005, с. 142.

22 А. Коваль, зазнач. джер, с. 221.

23 Е. Асенчик, указ. источ., с. 142.

${ }^{24}$ Т. Варлакова, Особенности семантики й функционирования многочленных фразеологических омонимов библейского происхождения, [в:] “И вновь продолжается бой...”, сб. науч. ст., посв. юбилею д-ра филол. наук, проф. С. Г. Шулежковой, гл. ред. В. М. Мокиенко, Магнитогорск 2010 , с. 61 . 
від хорошого' ${ }^{25}$, або ж кость від кості і плоть від плоті, що походять 3 одного фрагмента Старого Заповіту, у якому йдеться про створення жінки (2 : 21-23). Вони вживаються на позначення кровної або духовної близькості, глибоких почуттів і зв'язків між людьми ${ }^{26}$, або ж вавилонський полон і єгипетська неволя (єгипетський полон), що вживаються на позначення важкого, нужденного, підневільного життя ${ }^{27}$. Синонімічним є ФО-бібліїзми содом $i$ гоморра — 'велике безладдя; метушня, шум' ${ }^{28}$ і вавилонське стовпотворіння — 'про великий гурт людей, де панує галас, метушня, шум'29, причому ФО содом $і$ гоморра вступає в синонімічні зв'язки з іншими біблійними лексемами й $Ф О$, що позначають також катастрофу, яка наближається (Армагедон, Апокаліпсис, Страшний Суд та ін.). Очевидно, така багатозначність спричинена різними бібліємами, під якими розуміємо „певне узагальнене абстрактне значення, що сягає відповідного біблійного образу або сюжету, спільне для мов усіх народів, пов'язаних із християнською релігією”"30, а саме 'розпуста, гріх' і 'безлад, метушня', що виявляються в розглядуваному бібліїзмі.

Оказіональна (постбіблійна) ФО адамове ребро (реберие) має синонімічну оказіональну біблійну фразему Свин накоренок; крилате слово змій-спокусник (змій-іскуситель — нетранслітерований церковнослов' янський варіант) ${ }^{31}$ — 'хитра, підступна людина' - вступає в синонімічні зв'язки з оказіональною фраземою біблійного походження юдине коріння — 'підступна людина'32.

Бібліїзми-фразеологізми, як і лексичні бібліїзми, є символемами, що „формують певну систему, компоненти якої, по-перше, утворюють бінарні опозиції, а по-друге, - змістові грона, що увиразнюють та підсилюють сакральну семантику. У християнській системі цінностей протиставлення полюсів стає абсолютом, тому двовимірна архетипність добро / зло - верхівка ієрархії категорій віра / невіра, праведність / гріх, життя / смерть"з3.

Цілком очевидно, що така опозиція спричиняється до наявності серед бібліїзмів антонімічних протиставлень. Так, напр., антонімами-бібліїзмами $\epsilon$ лексеми пекло й рай. Відповідно, антонімічні пари утворюють ФО геєна огненна - 'місце загибелі грішників, пекло' ${ }^{34}$ і лоно Авраамове — 'рай, потойбічний світ' ${ }^{35}$.

Виразними, як видається, є опозиції, побудовані на основі біблійних власних назв, на що звернула увагу О. Решетняк, яка зауважила: „Символічна парадигма двох антропонімних дихотомій Авель(+) - Каӥн (-); Icyc Xристос (+) - Iуда (-) та асоціативно-образні парадигми символем 3 топонімними компонентами Еден (Едем), Ханаан (обіияна земля), Срусалим, Новий Срусалим (+); Сгипет, Содом і Гоморра, Вавилон, Вавилон Великий (-) є передусім імперативами зазначеної ієрархії морально-аксіологічних площин. Саме вони на тлі ін-

25 А. Коваль, зазнач. джер, с. 206.

26 Там само, с. 196.

27 Там само, с. 54.

28 Словник фразеологізмів украӥнської мови..., с. 676.

29 А. Коваль, зазнач. джер, с. 39.

${ }^{30}$ К. Дубровина, указ. источ.

31 А. Коваль, зазнач. джер, с. 21.

32 Ж. Колоїз, Слово Благовісті: словник-довідник фразем біблійного походження, Кривий Ріг 2002, с. 193.

33 О. Решетняк, Парадигма біблійних символів з онімним компонентом в украӥнській лінгвокультурі, Дніпропетровськ 2015, с. 294.

34 А. Коваль, зазнач. джер, с. 126.

35 А. Коваль, зазнач. джер, с. 250. 
ших онімів найчіткіше виокремлюють бінарні конотативно марковані зони позитивного і негативного модусів"з6. На високий ступінь канонічної регламентованості біблійних символем, чітке розмежування позитивних і негативних конотацій звертають увагу й інші дослідники, зокрема Г. Лукаш ${ }^{37}$.

Як і більшість ФО, фразеологізми-бібліїзми можуть мати варіанти, про що пише, напр., О. Кунін, який зазначив: „Фразеологізми біблійного походження не $\epsilon$ застиглими цитатами, що не допускають ніяких змін"з8. На прикладі англійської мови вчений доводить, що „багато з них обростає варіантами, зазнає різноманітного оновлення, від них можуть утворюватися похідні" 39 .

Це твердження цілком стосується й української мови, адже значна частина транслітерних біблійних ФО має варіанти, що, як правило, виникли внаслідок так званої тенденції відштовхування від церковнослов'янізмів: алчущі $i$ жаждущі - спраглі і голодні; віра горами двигає - віра горами рухає; глас вопіющзого в пустині - голос волаючого в пустелі; гроби поваплені - гроби побілені; юдоль плачу - долина плачу; земля обітована - обітована земля - обіияна земля; золотий телець - золоте теля; не сотвори собі кумира - не робі собі подоби; ничтоже сумняся (сумняшеся) - нічого сумніватися; своя свойх не познаша - своя своїх не пізнає; святая святих - свята святих - святеє святих; сильні мира сего - сильні світу иуього; співати осанну - співати славу; суєта суєт - марнота марнот; хліб насущзниц - хліб щуоденний; як тать уночі - як злодій уночі тощо"40.

Наявність варіантних змін у системі біблійних фразеологізмів підтверджує тезу про те, що вони не є статичними, а репрезентують ,живий і рухливий, постійно змінюваний мовний матеріал, що підтверджує його системний характер. Через варіативність відбувається розвиток фразеологічної підсистеми мови: первинно з'являючись у мовленні, варіанти біблійних фразеологічних одиниць фіксуються потім і в мовній системі" "41. Так, упродовж останніх двох десятиліть сформувався й встановився один з українських відповідників фразеологізмів козел відпущення - козел офірний - ияап-відбувайло ${ }^{42}$.

Отже, наявність у складі ФО церковнослов'янізмів різного типу, “законсервованих" біблійними крилатими виразами, є однією з головних, однак не обов’язкових (факультативних) експліцитних ознак біблійної маркованості, оскільки, по-перше, у багатьох ФО-бібліїзмах церковнослов'янізми замінені українськими словами; по-друге, як справедливо зазначає В. Хлебда, наявність власних імен й архаїзмів біблійного походження в складі сполучень слів й афоризмів далеко не завжди свідчить про їхню належність до корпусу бібліїзмів ${ }^{43}$.

36 О. Решетняк, зазнач. джер, с. 204.

37 Г. Лукаш, Алплітуда семантичного розширення власних назв, [в:] „Наукові записки Тернопільського національного педагогічного університету імені Володимира Гнатюка. Серія «Мовознавство»", 2017, № 1, с. 165.

38 А. Кунин, Курс фразеологии современного английского языка, Москва 1996, с. 227.

39 Там же, с. 227.

40 М. Скаб, Вплив Біблії на українську мову: обшир, аспекти та основні проблеми їх вивчення, [в:] „Науковий вісник Чернівецького національного університету імені Юрія Федьковича", зб. наук. праць, Чернівці 2016, вип. 772, с. 17.

41 А. Багдасарян, Вариантность библейской фразеологии как признак системности, [w:] Słowo. Tekst. Czas: Frazeologia w idiolekcie i systemach języków słowiańskich (W 200 rocznicȩ urodzin Tarasa Szewczenki), pod red. M. Aleksiejenki, H. Biłowus, M. Hordy, W. Mokijenki, H. Waltera, Szczecin-Greifswald 2014, t. 1, s. 385.

42 М. Скаб, зазнач. джер, с. 17.

43 W. Chlebda, К описанию библеизмов в двуязычном словаре, [w:] „Przegląd Rusycystyczny”, red. nacz. Wanda Zmarzer, Katowice 2002, № 4, s. 86-87. 
У системі бібліїзмів найменш виразними є гіперо-гіпонімічні, тобто родовидові, відношення. Як видається, вони виявляються у процесі зіставлення, напр., лексичного бібліїзму-гіпероніма гріх та його фразеологічних гіпонімів, що вказують на час скоєння гріха або ж на його різновид, порівн.: гріхи молодості, содомський гріх, смертний гріх, первородний гріх, або ж ФО-бібліїзму кара Господня з такими мовними одиницями, як кари єгипетські, вигнання з раю, що є вербалізаторами, власне, самого способу покарання.

Загалом же послідовний вияв парадигматичних відношень (полісемії, омонімії, антонімії, синонімії, варіативності, гіпер-гіпонімії) у бібліїзмів засвідчує їхню системність, а саму систему цих мовних одиниць характеризують відповідні закономірності їхнього творення, наявність внутрішніх властивостей і відношень між ними як одиницями системи й відношення цих фразеологічних одиниць до одиниць інших рівнів.

\section{Список використаної літератури}

Асенчик Е., О глубинной семантике фразеологизма не от мира сего, [в:] Славянская фразеология в ареальном, историческом и этнокультурном аспектах, матер. III Междунар. науч. конф. (Гомель, 7-8 октября 2003 г.), Гомель 2005, с. 141-144.

Багдасарян А., Вариантность библейской фразеологии как признак системности, [в:] Słowo. Tekst. Czas: Frazeologia w idiolekcie i systemach języków słowiańskich (W 200 rocznice urodzin Tarasa Szewczenki), pod red. M. Aleksiejenki, H. Biłowus, M. Hordy, W. Mokijenki, H. Waltera, Szczecin-Greifswald 2014, t. 1, s. 379-385.

Бурукина О., Цвета библейских фразеологизмов: истоки иветового символизма, [в:] Славянская фразеология и Библия. Slovanska frazeologia a Biblia, W. Harry, V. Mokienko, D. Balakova (ur.), Greifswald 2013, c. 59-69.

Валентинова О., О семантических последствиях отчуждения сакрального знака от канонического смыслообразующего контекста, [в:] Фразеологизм и слово в художественном, публицистическом и народно-разговорном дискурсах, матер. междунар. науч.-практ. конф. 18-23 марта 2016 года, под. науч. ред. И. Ю. Третьяковой, Кострома 2016, с. 80-82.

Варлакова Т., Особенности семантики и функиионирования многочленних фразеологических омонимов библейского происхождения, [в:] "И вновь продолжается бой...”, сб. науч. ст., посвящ. юбилею д-ра филол. наук, проф. С. Г. Шулежковой, гл. ред. В. М. Мокиенко, Магнитогорск 2010, с. 59-62.

Дубровина К., Библейские фразеологизмы в русской и европейской культуре, Москва 2012, [в:] Электронный ресурс: http://modernlib.ru/books/kira_nikolaevna_dubrovina/ bibleyskie_frazeologizmi_v_russkoy_i_evropeyskoy_kulture/read/ (15.11.2017).

Загнітко А., Словник сучасної лінгвістики: поняття і терміни, у 4 томах, Донецьк 2012.

Коваль А., Спочатку було Слово: Крилаті вислови біблійного походження в українській мові, Київ 2012.

Колоїз Ж., Слово Благовісті: словник-довідник фразем біблійного походження, Кривий Ріг 2002.

Космеда Т., Аксіологічні аспекти прагмалінгвістики: формування і розвиток категорії оцінки, Львів 2000.

Кузнецова И., Языковая шутка в устойчивых сравнениях с персонажем Библии, [в:] Славянская фразеология и Библия. Slovanska frazeologia a Biblia, W. Harry, V. Mokienko, D. Balakova (ur.), c. 123-129.

Кунин А., Курс фразеологии современного английского языка, Москва 1996.

Лепта библейской мудрости: библейские крылатые выражения и афоризмы на шести языках: краткий русско-англо-белорусско-немеико-словаико-украинский словарь, Могилев 2014.

Лисиченко Л., Лексико-семантична система української мови, Харків 1997. 
Лукаш Г., Амплітуда семантичного розширення власних назв, [в:] „Наукові записки Тернопільського національного педагогічного університету імені Володимира Гнатюка. Серія «Мовознавство»", 2017, № 1, с. 204-209.

Перша заповідь блаженств: “Блаженні вбогі духом, бо таких є Царство Небесне”, [в:] Електронний ресурс: http://www.truechristianity.info/ua/books/hope_for_lord_031. php (22.12.2017).

Решетняк О., Парадигма біблійних символів з онімним компонентом в украӥнській лінгвокультурі, Дніпропетровськ 2015.

Скаб М., Вплив Біблії на украӥнську мову: общир, аспекти та основні проблеми їх вивчення, [в:] „Науковий вісник Чернівецького національного університету імені Юрія Федьковича", зб. наук. праць, Чернівці 2016, вип. 772, с. 13-20.

Словник фразеологізмів украӥнської мови, Київ 2008.

Chlebda W., К описанию библеизмов в двуязычном словаре, [w:] „Przegląd Rusycystyczny” red. nacz. Wanda Zmarzer, Katowice 2002, № 4, s. 86-105.

\section{Spysok vykorystanoi literatury [References]}

Asenchik E., O glubinnoj semantike frazeologizma ne ot mira sego [About Deep Semantics of Weird Phraseologism], [v:] Slavyanskaya frazeologiya v areal'nom, istoricheskom $i$ e tnokul 'turnom aspektah, mater. III Mezhdunar. nauch. konf. (Gomel', 7-8 oktyabrya 2003 g.), Gomel' 2005, s. 141-144.

Bagdasarjan A., Variantnost biblejskoj frazeologii kak priznak sistemnosti [Variance of Biblical Phraseology as Systematicity Feature], [v:] Stowo. Tekst. Czas: Frazeologia $w$ idiolekcie $i$ systemach języków słowiańskich (W 200 rocznice urodzin Tarasa Szewczenki), pod red. M. Aleksiejenki, H. Biłowus, M. Hordy, W. Mokijenki, H. Waltera, Szczecin-Greifswald 2014, t. 1, s. 379-385.

Burukina O., Czveta biblejskih frazeologizmov: istoki czvetovogo simvolizma [Colours of Biblical Phraseologisms: Sources of Colour Symbolism], [v:] Slavyanskaya frazeologiya i Bibliya. Slovanska frazeologia a Biblia, W. Harry, V. Mokienko, D. Balakova (ur.), Greifswald 2013, s. 59-69.

Valentinova O., O semanticheskih posledstviyah otchuzhdeniya sakral'nogo znaka ot kanonicheskogo smysloobrazuyushhego konteksta, [About Semantic Consequences of Sacred Sign Estrangement from Canonic Sense Forming Context], [v:] Frazeologizm i slovo $v$ hudozhestvennom, publicisticheskom i narodno-razgovornom diskursah, mater. mezhdunar. nauch.-prakt. konf. 18-23 marta 2016 goda, pod. nauch. red. I. Yu. Tret'yakovoj, Kostroma 2016, s. 80-82.

Varlakova T., Osobennosti semantiki i funkcionirovaniya mnogochlennih frazeologicheskih omonimov biblejskogo proishozhdeniya [Peculiarities of Semantics and Functioning of Multicomponental Phraseological Homonyms of Biblical Origin], [v:] “I vnov' prodolzhaetsya boj ...", sb. nauch. st., posvjashh. yubileyu d-ra filol. nauk, prof. S. G. Shulezhkovoj, gl. red. V. M. Mokienko, Magnitogorsk 2010, s. 59-62.

Dubrovina K., Biblejskie frazeologizmy v russkoj i evropejskoj kulture [Biblical Phraseologisms in Russian and European Culture], Moskva 2012, [v:] E’lektronnyj resurs: http: // modernlib.ru/books/kira_nikolaevna_dubrovina/bibleyskie_frazeologizmi_v russkoy_i_evropeyskoy_kulture/read/ (15.11.2017).

Zahnitko A., Slovnyk suchasnoi linhvistyky: poniattia i terminy [Dictionary of Modern Linguistics: Notions and Terms], u 4 tomakh, Donetsk 2012.

Koval A., Spochatku bulo Slovo: Krylati vyslovy bibliinoho pokhodzhennia v ukrainskii movi [In the Beginning there was a Word: Phrases of Biblical Origin in the Ukrainian Language], Kyiv 2012.

Koloiz Zh., Slovo Blahovisti: slovnyk-dovidnyk frazem bibliinoho pokhodzhennia [Word of Blahovist: Dictionary of Phrasemes of Biblical Origin], Kryvyi Rih 2002. 
Kosmeda T., Aksiolohichni aspekty prahmalinhvistyky: formuvannia i rozvytok katehorii otsinky [Ego and Alter Ego of Taras Shevchenko in Communicative Space of Diary Discourse], Lviv 2000.

Kuzneczova I., Jazykovaja shutka v ustojchivyh sravnenijah s personazhem Biblii [Language Joke in Stable Comparisons with Biblical Hero], [v:] Slavyanskaya frazeologiya i Bibliya. Slovanska frazeologia a Biblia, W. Harry, V. Mokienko, D. Balakova (ur.), s. 123-129.

Kunin A., Kurs frazeologii sovremennogo anglijskogo yazyka [Phraseology Course of Modern English], Moskva 1996.

Lepta biblejskoj mudrosti: biblejskie krylatye vyrazheniya $i$ aforizmy na shesti yazykah: kratkij russko-anglo-belorussko-nemeczko-slovaczko-ukrainskij slovar' [Lepton of Biblical Wisdom: Biblical Phrases and Aphorisms in Six Languages: Concise Russian-English-Belorussian-German-Slovakian-Ukrainian Dictionary], Mogilev 2014.

Lysychenko L., Leksyko-semantychna systema ukrainskoi movy [Lexico-Semantic System of the Ukrainian Language], Kharkiv 1997.

Lukash H., Amplituda semantychnoho rozshyrennia vlasnykh nazv [Amplitude of Proper Names Semantic Broadening], [v:] „Naukovi zapysky Ternopilskoho natsionalnoho pedahohichnoho universytetu imeni Volodymyra Hnatiuka. Ser. «Movoznavstvo»", 2017, № 1, s. 204-209.

Persha zapovid blazhenstv: "Blazhenni vbohi dukhom, bo takykh ye Tsarstvo Nebesne" [Beatific the Poor by Spirit, because theirs is Heaven Kingdom], [v:] Elektronnyi resurs: http://www.truechristianity.info/ua/books/hope_for_lord_031.php (22.12.2017).

Reshetniak O., Paradyhma bibliinykh symvoliv $\bar{z}$ onimnym komponentom $v$ ukrainskii linhvokulturi [Biblical Symbols Paradigm with Onym Component in Ukrainian LinguoCulture], Dnipropetrovsk 2015.

Skab M., Vplyv Biblii na ukrainsku movu: obshyr, aspekty ta osnovni problemy yikh vyvchennia [The Bible Influence on the Ukrainian Language: Scope, Aspects and Main Problems of their Investigation], [v:] „Naukovyi visnyk Chernivetskoho natsionalnoho universytetu imeni Yuriia Fedkovycha", zb. nauk. prats, Chernivtsi 2016, vyp. 772, s. 13-20.

Slovnyk frazeolohizmiv ukrainskoi movy [Dictionary of Ukrainian Phraseologisms], Kyiv 2008.

Chlebda W., Kopisaniyu bibleizmov v dvuyazychnom slovare, [w:] „Przegląd Rusycystyczny” red. nacz. Wanda Zmarzer, Katowice 2002, № 4, s. 86-105. 